\title{
Andosols: a vulkáni anyagon kifejlődött ásványi talajok
}

\section{Az Andosolok kialakulása és elterjedése, a klasszifikáció kezdetei}

Az „Andosol” japán eredetű szó, sötét (An) talajt (Do) jelent (THORP \& SMITH, 1949), amely egyre inkább nemzetközileg is elfogadott és használt terminussá kezd válni a vulkáni talajok szakirodalmában. Korábban számos helyi elnevezés létezett (és természetesen létezik ma is), mint a Kuroboku (Japán), a Trumao soils (Chile), Black Dust soil és High Mountain soils (Indonézia), a Soapy hill (India), vagy a Yellow Brown Loams (Új-Zéland).

Az Andosolok intrazonális talajok, amelyek elsősorban vulkáni (kőzetüvegben gazdag) piroklasztikumon, főleg vulkáni tufán alakulnak ki, de ugyanúgy kifejlődhetnek láván, törmeléken, ár- és lahar üledékeken, gyakorlatilag bármilyen összetételü vulkanikus anyagon (NEALL, 1985). Kifejlődésük elsősorban a Föld csapadékosabb, vulkanikus régióihoz kötődik, de előfordulhatnak a legkülönbözőbb klímafeltételek mellett is. Megtalálhatók pl. Alaszka, ill. Hokkaido hűvös, nedves klímáján éppúgy, mint Kyushu szubtrópusi, Hawaii trópusi félig száraz éghajlatán. Ennek megfelelően Európában Izlandtól a Kanári-szigeteken át Dél-Olaszországig több helyen előfordulnak.

Az elmúlt évek behatóbb vizsgálatai után azonban, egyre több tanulmány látott napvilágot, amelyek nemcsak friss vulkáni anyagon azonosítottak Andosolokat, hanem pl. 30-40 000 éves bazalton Németországban, több millió éves piroxén andeziten a KeletiKárpátokban, vagy akár variszkuszi grániton Ausztriában (KLEBER et al., 2004; DELVAuX et al., 2004; JAKAB et al., 2004; BÄUMLER, 2004; GARCIA-RODEJA et al., 2004). Kialakulásukban igen fontos szerep jut az ásványos összetételnek és a nedves klímának.

Az Andosolok tudománytörténete fiatal. A nemzetközi talajtan csak a XX. század közepén ismerte fel és kezdett foglalkozni a vulkáni talajokkal, mint önálló talajcsoporttal. Az első definíció 1949-ben született THORP és SMITH (1949) tollából, majd első alkalommal, mint vulkáni hamu talajok a Soil Taxonomy (amerikai talajosztályozási rendszer)-ben klasszifikálták e típust (SOIL SURVEY STAFF, 1960). A FAO talajosztályozásába, mint fó talajcsoport csak 1974-ben került be, a FAO/UNESCO TalajVilágtérkép elkészítése során (FAO-UNESCO, 1974). Az Andosolok eredeti definíciója, amelynek jelentősen továbbfejlesztett változatát használja a FAO/UNESCO, az amerikai talajosztályozási rendszerből származik (SOIL SURVEY STAFF, 1975). Azóta hatalmas mennyiségü ismeretanyag halmozódott fel, amely egyrészről szükségessé tette, másrészről megkönnyítette ezen klasszifikációs rendszerek figyelemre méltó fejlődését, tökéletesítését. Az ebben élenjáró két legfontosabb munkacsoport az ICOMAND (International Committee on the Classification of Andisols) és az IUSS WRB (International Union of Soil Sciences World Reference Base for Soil Resources) volt. 
A legfontosabb változás az osztályozási irányelvekben történt. Az agyagásványokról szóló ismeretanyag bővülésével egyre inkább az „,andic” tulajdonság megléte lett az osztályozás fő szempontja, a korábbi - ,amorf anyag és kicserélhető komplexek” hangsúlyozta - szemlélettel szemben (ICOMAND, 1983). Ebből a szempontból jelentős PARFITT és munkatársai (1984) munkája, amelyben nagyszámú andic tulajdonságot határoz meg.

\section{Az Andosolok legfontosabb tulajdonságai}

Az Andosolok legfontosabb tulajdonságai a következő szempontok szerint csoportosíthatók (MOHR et al., 1972; LEAMY et al., 1980; WADA et al., 1986; WADA \& KAKUTO, 1985; MIZOTA \& VAN REEUWIJK, 1989; ISSS-ISRIC-FAO, 1998; FITZPATRICK, 1972):

Morfológia. - A-, AC- vagy A-, B- és C-szintek különíthetők el, ahol az A (Ah)szint átlagos vastagsága $20-50 \mathrm{~cm}$, de ez lehet $20 \mathrm{~cm}$-nél kevesebb, vagy akár $100 \mathrm{~cm}$ is. A B-szint 20-30 cm vastag. Az egész profilban a sötét színek dominálnak, többnyire sötétbarna-fekete, ami a nagy humusztartalomnak köszönhetö. Hüvösebb klíma alatt sötétebb színü, mint a trópusi éghajlat alatt képződött, mivel ez utóbbinál jelentősen kevesebb a szervesanyag-felhalmozódás. Mindkét szint morzsás, szemcsés szerkezetü, nagyon könnyü, porózus. Nedves állapotban kenődő, csúszós, zsíros tapintású. A Bszint többnyire tixotróp, azaz dörzsölve képlékennyé válik és nedvességet bocsát ki, de a dörzsölés befejeztével újra megkeményedik.

A B-szint fokozatosan megy át a C-szintbe, a vulkáni anyagba, amely többnyire vulkáni hamu. Gyakran több eltemetett talajszint is jelen van az egymást követő hamuszórások eredményeként.

Talajképző kőzet. - Amint említettük, elsősorban vulkáni (kőzetüvegben gazdag) piroklasztikumon, föleg vulkáni tufán alakulnak ki, de ugyanúgy kifejlődhetnek vulkáni láván, törmeléken, ár- és lahar üledékeken, gyakorlatilag bármilyen összetételü vulkanikus anyagon. Tehát származhatnak a légkörböl egy vulkánkitörést követő hamuszórás eredményeként, de lehet áthalmozott anyag is, mint például folyóvízi üledék.

Éghajlati tényezők. - Az Andosolok kialakulását főként az anyakőzet tulajdonságai határozzák meg, de kifejlődésükben igen fontos szerep jut a klimatikus tényezőknek is. Elsősorban nedves körülmények között fordulnak elő, a sarkvidékektől a trópusokig. Leggyorsabb kifejlődésük nedves trópusi körülmények között lehetséges. Lassabban ugyan, de hüvös-nedves klímán éppúgy kialakulhatnak. Száraz, nagyon száraz körülmények között nem fejlödnek ki.

Ásványos összetétel. - Mind a vályog-, mind a homokfrakció tartalmaz vulkáni üveget, amelynek mennyisége helyileg változó. Néhány ásványszemcsét vulkáni üvegbevonat fedhet.

A vulkáni üveg hidrolízise nyomán először palagonit (amorf Al-szilikát, amely kalciumot, magnéziumot és káliumot tartalmaz), majd viszonylag gyorsan allofán és imogolit keletkezik. Erőteljes mállás esetén halloysit és más kristályos ásványok képződhetnek. A vulkáni üveg bomlásakor alumínium és vas kerül oldatba, amelyek stabil komplexeket alkotnak a humusszal.

Leggyakoribb ásványok a vas-, mangánásványok (olivin, piroxén, amfibol), a földpátok és a kvarc. Mennyiségük a vulkáni anyag természetétől függ. 
Az Andosolok agyagásvány-összetételét több tényező határozza meg, így a talajképződés foka, a talajképző kőzet összetétele, a pH és a nedvességviszonyok, a hamurétegek vastagsága vagy a szerves anyag mennyisége. A humusznak fontos szerep jut az alumíniummal, és kisebb mértékben a vassal alkotott komplexekben. A legtöbb esetben

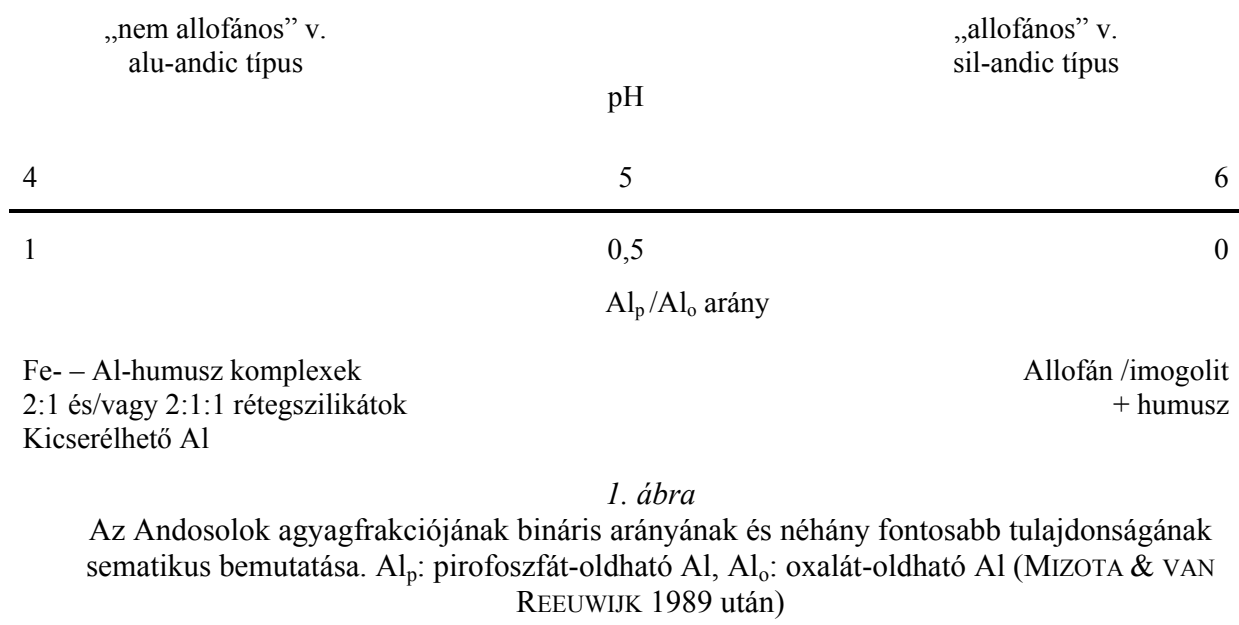

az amorf agyagásványok (allofán, ritkábban imogolit) is jelen vannak. Az amorf anyagok és az Al-, Fe-humusz komplexek együtt fordulhatnak elö, de többnyire fordított arány figyelhető meg közöttük, amely a kialakulás különböző körülményeit tükrözi (1. ábra) (SHOJI et al., 1982; WADA, 1977; WADA et al., 1986; MiZOTA \& VAN REEUWIJK, 1989).

Fizikai-kémiai tulajdonságok. - Térfogattömegük alacsony, általában nem éri el a $0,9 \mathrm{~g} / \mathrm{cm}^{3}$ értéket.

Nagy humusztartalmúak (átlagosan 8\%), a szervesanyag-tartalom elérheti a 30\%-ot is, amely stabil komplexeket alkothat.

$\mathrm{Az}$ ioncserélő képesség jelentős különbségeket mutat a $\mathrm{pH}$ függvényében. Míg a kationkicserélő képesség növekszik a pH-val, az anionkicserélő csökken. A magas humusztartalom következtében a kationkicserélö képesség a felső szintben általában magas (35 me\% feletti is lehet), míg a középső szintben már csak 10-15 me\%. Mindazonáltal a fenti értékeket óvatosan kell kezelni, mivel az allofán nem úgy viselkedik, mint más agyagásványok, illetve az értékek erősen függenek a mérési technikától is.

E talajok mérsékelten vagy erősen savanyúak, akár 4,5-es felszíni pH-értékkel, amely a mélységgel lassú növekedést mutat. Allofán és imogolit többsége esetén a $\mathrm{pH}$ viszonylag magas (> 5), ugyanakkor Al- és Fe-humusz komplexek dominanciája esetén a $\mathrm{pH}<5$ (1. ábra). Vagyis az allofántartalom a mélységgel nő, míg az Al-, Fe-humusz komplexek aránya a felszín felé növekszik.

$\mathrm{Az}$ agyagtartalom általában nem haladja meg a 20-25\%-ot. A legnagyobb mennyiségben a legfelső rétegben fordul elö és a mélységgel csökken a részaránya. Az alsóbb rétegekben mennyisége akár 5\% alá is csökkenhet. 
A „fluffiness” (könnyü, pihés szerkezet) és a nagy - 70\%-ot is meghaladó - porozitás fontos és jellemző tulajdonság. Mindkét tulajdonság a hidrolízis fő termékének, az allofánnak köszönhető.

A bázistelítettség szintén alacsony. A felszín közelben a legalacsonyabb és a mélység felé növekszik az értéke, de a müvelés hatására a felső szintben is elöfordulhatnak magas értékek.

Erős a foszformegkötő képességük.

Víztartó képességük igen nagy. Víztartalmuk 15 bar nyomás mellett több mint 20\%, de nem szokatlan a 100\%, vagy annál több sem (FLACH, 1964). Ez az allofán nagy fajlagos felületének köszönhetö, amely $\mathrm{kb} .1000 \mathrm{~m}^{2} \cdot \mathrm{g}^{-1}$.

Kiszáradásuk néhány tulajdonságban visszafordíthatatlan változást okozhat, pl. a vízfelvételben, vagy az ionkicserélő képességében (ANDRIESSE et. al., 1976; COLMETDAAGE, 1978; FÜLEKY, 2004).

Topográfiai helyzet. - A nagyon meredektől a sík térszínekig, bármilyen magasságban, bárhol létrejöhetnek, de kialakulásukhoz legkedvezőbbek a viszonylag stabil, sík vagy kissé lejtős területek.

Növényzet. - A növényzet ugyanolyan változatos lehet, mint amilyen változatos éghajlati körülmények között előfordulhat e talajtípus. Az Andosolokon kifejlődött természetes növénytársulások gyakran gazdagabbak, bujábbak, mint a hasonló helyen, de eltérő talajképző kőzeten kialakult talajokon élő társulások, ami a finomszemű vulkáni anyag gyorsabb mállásának köszönhető, amely bőségesebb tápanyagellátást biztosít e talajok számára.

\section{Andosols, a WRB talajesoportja}

A World Reference Base for Soil Resources (WRB) a Nemzetközi Talajtani Unió (IUSS), az International Soil Reference and Information Centre (ISRIC) és a FAO (Food and Agriculture Organization of the UN) által támogatott és létrehozott közös nemzetközi talajosztályozási rendszer (ISSS-ISRIC-FA, 1998). A diagnosztikai szemléletü korrelációs talajosztályozási rendszer első szintjén 30 ún. „Referencia Talajcsoportot” (Reference Soil Group) különít el. A további szint(ek)et az ún. „minősítők” (qualifier) határozzák meg. A „minősítő”” referencia csoportonként, táblázatos formában, prioritási sorrendben vannak felsorolva. Minden minősítőnek diagnosztikai kategóriára épülö tartalma van.

A földi talajtakaró egységes térképének és osztályozási rendszerének igénye már az 1950-es években felmerült, de végül csak 1960-ban indult ez a nagyszabású munka, több mint 300 szakember bevonásával. A teljes Földet lefedő talajtérkép és osztályozási rendszer így is csak 1981-re készült el 1:5M méretarányban (a tervezett 1:1M helyett). Idöközben - a folyamatos javításoknak és pontosításoknak köszönhetően - a talajosztályozási rendszer több változata látott napvilágot.

A WRB talajosztályozási rendszer az egyes osztályozási egységek felismerésére és elkülönítésére jól definiált fogalmakat ír le: „diagnosztikus talajszintek”, „diagnosztikus tulajdonságok”, „diagnosztikus talajanyagok”. A talajok besorolása kulcs alapján, a fentiek jelenléte, sorrendje, esetleg kizárása alapján történik. Kevésbé szubjektív egy genetikus talajosztályozási rendszernél, hiszen mindent pontos vizsgálati értékekhez 
köt. Így amennyiben rendelkezünk a megfelelő vizsgálati módszerekkel és eredményekkel, könnyen és gyorsan besorolhatjuk a kérdéses talajt a megfelelő talajcsoportba.

A WRB külön talajcsoportként kezeli a vulkáni anyagon képződött ásványi talajokat. Az Andosols talajok becsült területi kiterjedése 124-150 millió ha, amely a földfelszín mindössze 0,84-1\%-át jelenti. Jelentőségüket mégis az adja, hogy ennek a $80 \%$-a potenciális mezőgazdasági terület. Ez a mezőgazdasági területeknek mintegy 2\%-át jelenti, de több mint a fele a trópusokon található, így a világ népességének több mint 10\%-át látja el élelemmel (LEAMY et al., 1980; PING, 2000).

\section{A WRB Andosols kritériumrendszere}

A WRB alapján Andosols-ként azonosíthatunk talajt, amennyiben a következő két feltételnek eleget tesz:

1. olyan andic vagy vitric szintjük van, melynek felső határa a talajfelszíntől számított $25 \mathrm{~cm}$-en belül van, és

2. histic, fulvic, melanic, mollic, umbric, ochric, duric vagy cambic szinten kívül egyéb diagnosztikai szintek nem fordulnak elő (hacsak azok nincsenek 50 cm-nél mélyebbre eltemetve).

Andic szint általában erős mállás jelenlétében alakul ki, így már kevesebb vulkáni üveget, de nagyobb mennyiségü oxalát-oldható alumíniumot és vasat tartalmaz. Két típusát különíthetjük el a bennük található allofán és Al-humusz komplexek aránya alapján: A sil-andic típus nagy allofántartalommal és gyengén savas $\mathrm{pH}$-val jellemezhető, míg az alu-andic típusú szintekben az Al-humusz komplexek dominálnak, erősen savas $\mathrm{pH}$ mellett. Az andic szint diagnosztikai feltételeiről a 1. táblázat nyújt áttekintést.

A vitric szint igen szoros kapcsolatban áll az andic szinttel. Többnyire gyenge mállás eredményeként jön létre. Nagymennyiségü vulkáni üveget és kevés oxalát-oldható alumíniumot és vasat tartalmaz. Gyakorlatilag gyengén fejlett andic szintnek tekinthetö, amely idővel andic szintté fejlödhet. A vitric szint kritériumait ugyancsak az 1. táblázat foglalja össze.

Ebből következik, hogy minden Andosol minimum vitric szinttel kell, hogy rendelkezzen. A vitric Andosolokat követik a sil-andic Andosolok, míg a legfejlettebbnek az alu-andic csoport tekinthetö.

1. táblázat

Az andic szint, ill. vitric szint diagnosztikai kritériumai (a finom föld frakcióban)

\begin{tabular}{|l|c||l|l|}
\hline \multicolumn{2}{|c||}{ Andic szint } & \multicolumn{2}{c|}{ Vitric szint } \\
\hline \multicolumn{1}{|c||}{ Tulajdonság } & Érték & Tulajdonság & \multicolumn{1}{c|}{ Éték } \\
\hline $\mathrm{Al}_{\mathrm{o}}+1 / 2 \mathrm{Fe}_{\mathrm{o}}$ & $>2 \%$ & Vulkáni üveg & $\leq 10 \%$ \\
Térfogattömeg & $<0,9 \mathrm{~g} \cdot \mathrm{cm}^{-3}$ & Agyagtartalom & $<10 \%$, vagy \\
P retenció & $>70 \%$ & Térfogattömeg & $>0,9 \mathrm{~g} \cdot \mathrm{cm}^{-3}$, vagy \\
Agyagtartalom & $>10 \%$ & $\mathrm{Al}_{\mathrm{o}}+1 / 2 \mathrm{Fe}_{\mathrm{o}}$ & $>0,4 \%$, vagy \\
Vastagság & $\geq 30 \mathrm{~cm}$ & P retenció & $>25 \%$ \\
Vulkáni üveg & $<10 \%$ & Vastagság & $\geq 30 \mathrm{~cm}$ \\
Andosol & andic szint megléte a & Andosol & vitric szint megléte a \\
& felszíntől $25 \mathrm{~cm}$-en belül & & felszíntöl $25 \mathrm{~cm}$-en belül \\
\hline
\end{tabular}


Mint azt fentebb az Andosolok definíciójában leírtam, a felszíntől számított $50 \mathrm{~cm}$ en belül összesen (az andic és vitric szintet kivéve) 8 egyéb diagnosztikai szint fordulhat elö. $50 \mathrm{~cm}$-nél mélyebben - pl. eltemetett talajszintként - azonban azonosíthatunk ezeken kívül más talajszinteket is.

Az „Andosols” meghatározásához, ill. fejlődéstörténetük és a bennük lejátszódó folyamatok jobb megértéséhez a következő „minősítők” (qualifier) nyújtanak segítséget:

$\begin{array}{llll}\text { Vitric } & \text { Hydric } & \text { Luvic } & \text { Arenic } \\ \text { Eutrisilic } & \text { Pachic } & \text { Placic } & \text { Sodic } \\ \text { Silic } & \text { Histic } & \text { Leptic } & \text { Skeletic } \\ \text { Gleyic } & \text { Mollic } & \text { Acroxic } & \text { Thaptic } \\ \text { Melanic } & \text { Duric } & \text { Vetic } & \text { Dystric } \\ \text { Fulvic } & \text { Umbric } & \text { Calcaric } & \text { Eutric } \\ & & & \text { Haplic }\end{array}$

(A minősítők részletes ismertetése jelen tanulmánynak nem feladata, de leírásuk megtalálható a World Reference Base for Soil Resources (ISSS-ISRIC-FAO, 1998) kiadványban.)

\section{Andic tulajdonságok a különböző talajosztályozási rendszerekben}

A vulkáni talajokat érintő tudományos ismeretanyag és a kutatások gyarapodásával az Andosolok fö kritériumát jelentő andic szintet meghatározó paraméterek egyre pontosabbak lettek. Az európai, egyesült államokbeli és egyéb talajosztályozások más-más kritériumaiból adódóan, mind a mai napig nincs teljesen egységes kritériumrendszer. A különböző rendszerek a talajok fő osztályozási tulajdonságaiban általában megegyeznek, de az értékek kisebb-nagyobb mértékben eltérnek egymástól (2. táblázat).

$\mathrm{Az}$ osztályozás kritériumai nemcsak rendszerenként, hanem időben is változtak. Az európai WRB (World Reference Base for Soil Resources) rendszer például az 1980-as évek végén még úgy fogalmazott, hogy az andic szint a „felszíntől számított $35 \mathrm{~cm}$-en belül, vagy mélyebben" helyezkedhet el, míg a legutóbbi WRB kézikönyvben ez a határ 25 cm-re csökkent (ISSS-ISRIC-FAO, 1998).

Az Andosolok kutatásával, kritériumaival, a klasszifikációs rendszerének problémáival mind a mai napig nemzetközi kutatógárda foglalkozik. Az Európai Uniós támogatású COST program keretében például a legnevesebb európai szakemberek álltak össze az európai Andosolok minél pontosabb megismerése, feltérképezése és klasszifikációs kérdéseik tisztázása érdekében. Eredményeik hamarosan az izlandi Rala Egyetem kiadásában (Szerk.: ARNALDS, O.) látnak napvilágot, valamint az újból kiadott WRB határozó könyvben. Az új kiadásban ismét jelentős változtatások várhatók az Andosolok és a diagnosztikai szintek (andic, vitric) kritériumait tekintve.

2. táblázat

Az andic szint néhány kritériuma a különböző talajosztályozásokban

(ISSS-ISRIC-FAO, 1998; SOIL SURVEY STAFF, 1998; ICOMAND, 1988)

\begin{tabular}{|l|c|c|c|}
\hline Tulajdonságok & WRB & USDA & ICOMAND \\
\hline $\mathrm{Al}_{\mathrm{o}}+1 / 2 \mathrm{Fe}_{\mathrm{o}}$ & $>2 \%$ & $>2 \%$ & $\geq 2 \% \mathrm{vagy} \geq 0,4 \%$ \\
Térfogattömeg & $<0,9 \mathrm{~g} \cdot \mathrm{cm}^{-3}$ & $<0,9 \mathrm{~g} \cdot \mathrm{cm}^{-3}$ & $\leq 0,9 \mathrm{~g}^{-3} \mathrm{~cm}^{-3}$ \\
P retenció & $>70 \%$ & $>85 \%$ & $>85 \% \mathrm{vagy}>25 \%$ \\
\hline
\end{tabular}




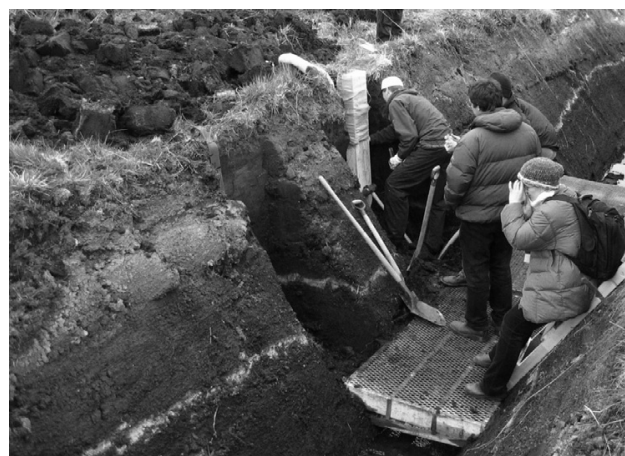

Andosol tefrával, Akureyri (Izland)

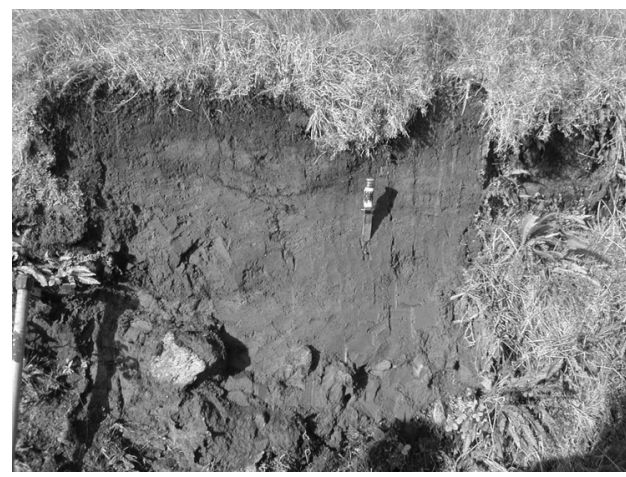

Andosol vulkáni hamun, São Miguel-sz. (Azori-szigetek, Portugália)

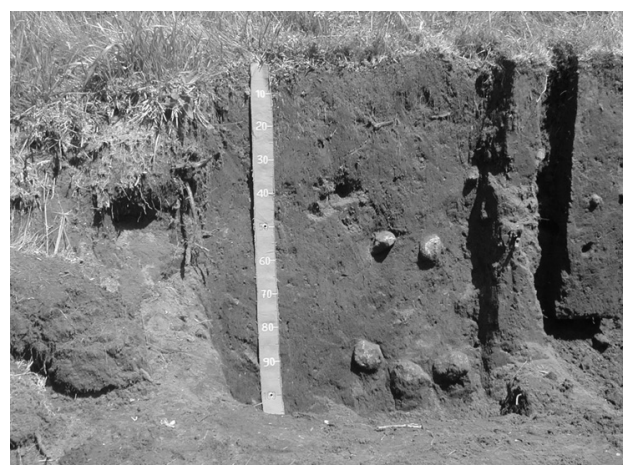

Andosol bazalton, Clermont Ferrand (Franciaország)

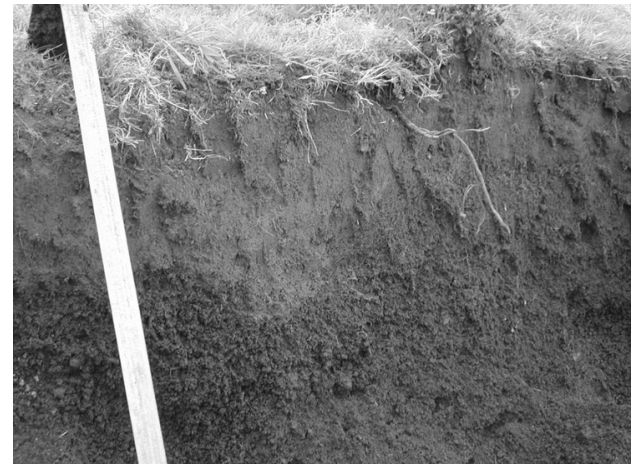

Andosol salakon, Terceira-sz.

(Azori-szigetek, Portugália)

\section{Irodalom}

Andriesse, J. P., van Rosmalen, H. A. \& Muller, A., 1976. On the variability of amorphous materials in Andosols and their relationships to irreversible drying and P-retention. Geoderma. 16. 125-138.

BÄUMLER, R., 2004. Soil development processess in non-volcainic Andosols. Rala Report No. 214. Reykjavík. 72-73.

Colmet-DaAgE, F., 1978. Caractéristiques et propriétés hydriques de quelques sols dérivés de cendres volcaniques du Chili central. Publ. ORSTOM-Antilles No. 85. (3me ed.). ORSTOM. Bondy, France

Delvaux, B. et al., 2004. An Andosol-Cambisol toposequence on granite in the Austrian Bohemian Massif. Catena. 56. (1-3) 31-43.

FAO-UNESCO Soil Map of the World, 1974. Vol. I. Legend. Unesco. Paris.

FitzPATRICK, E. A., 1972. Soils - Their Formation, Classification and Distribution. Longman. London.

FlaCH, K. W., 1964. Genesis and morphology of ash-derived soils in the United States of America. In: FAO World Soil Resources Report No. 14. 61-70. FAO. Rome.

FÜLEKY, G. 2004. Phosphate sorption of European volcanic soils. Rala Report No. 214. Reykjavik, 100-101. 
García-Rodeja, E. et al., 2004. Soils with andic properties developed from non-volcanic materials. Genesis and implications in soil classification. Rala Report No. 214. Reykjavík. 74-75.

ICOMAND, 1983. Circular Letter No. 5. Int. Comm. Classification of Andisols. Soil Bureau. Lower Hutt, New Zealand.

ICOMAND, 1988. Circular Letter No. 10. Int. Comm. Classification of Andisols. Soil Bureau. Lower Hutt, New Zealand.

ISSS-ISRIC-FAO, 1998. World Reference Base for Soil Resources. Wageningen/Rome.

JAKAB, S., FÜlEKY, G. \& FeHÉR, O., 2004. Environmental conditions of Andosols formation in Transylvania (Romania). Soils of the Gurghiu volcanic chain. Rala Report No. 214. Reykjavik. 65-66.

Kleber, M., Mikutta, C. \& Jahn, R., 2004. Andosols in Germany - pedogenesis and properties. Catena. 56. (1-3) 67-83.

LEAMY, M. L. et al., 1980. The morphological characteristics of Andisols. In: Soils with Variable Charge. (Ed.: ThENG, B. K. G.) 17-34. Soil Bureau. Lower Hutt, New Zealand.

Mizota, C. \& van ReeuwiJK, L. P., 1989. Clay Minerology and Chemistry of Soils Formed in Volcanic Material in Diverse Climatic Regions. ISRIC Soil Monograph. 2. Wageningen.

Mohr, E. C. J., van Baren, F. A. \& van Schuylenborgh, J., 1972. Tropical Soils. $3^{\text {rd }}$ ed. Mouton. The Hague.

NeALl, V. E., 1985. Parent materials of Andisols. In: Proc. $6^{\text {th }}$ Int. Soil Classif. Workshop, Chile and Ecaudor. Part 1. 9-19.

Parfitt, R. L., SAigusa, M. \& Cowie, J. D., 1984. Allophane and halloysite formation in a volcanic ash bed under different moisture conditions. Soil Sci. 138. 360-364.

Ping, Chien-Lu, 2000. Volcanic soils In: Encyclopedia of Volcanoes. (Ed.: Sigurdsson, H.) 1259-1270. Academic Press. San Diego.

SHOJI, S. et al., 1982. Chemistry and clay mineralogy of Ando soils, brown forest soils and podzolic soils formed from recent Towada ashes, N. E. Japan. Soil Sci. 133. 69-86.

Soll Survey Staff, 1960. Soil Classification, A Comprehensive System $-7^{\text {th }}$ Approximation. USDA. Washington, D. C.

SoIl Survey StAFF, 1975. Soil Taxonomy. A Basic System of Soil Classification for Making and Interpreting Soil Surveys. Agricultural Handbook No. 436. USDA. Washington, D. C.

SoIL SURVEY STAFF, 1998. Keys to Soil Taxonomy. $8^{\text {th }}$ ed. USDA-Natural Resources Conservation Service. Washington, D. C.

ThORP, J. \& SMith, G. D., 1949. Higher categories of soil classification: Order, Suborder and Great Soil Groups. Soil Sci. 67. 117-126

WADA, K., 1977. Allophane and imogolite. In: Minerals in Soil Environments. (Eds.: DiXON, J. B. \& WeED, S. B.) 603-638. SSSA. Madison, WI.

WADA, K. \& KAKUTO, Y., 1985. Embryonic halloysites in Ecuadorian soils derived from volcanic ash. Soil Sci. Soc. Am. J. 49. 1309-1318.

WADA, K., KAKUTO, Y., IKAWA, H., 1986. Clay minerals, humus complexes and classification of four „Andepts” of Maui, Hawaii. Soil Sci. Soc. Am. J. 50. 1007-1013.

Érkezett: 2005. szeptember 7.

MADARÁSZ BALÁZS

MTA Földrajztudományi Kutatóintézet, Budapest

Postai cím: MADARÁSZ BALÁZS, MTA Földrajztudományi Kutatóintézet, 1112 Budapest, Budaörsi út 45. E-mail: madaraszb@sparc.core.hu 